\title{
Buckwheat phenolic metabolites in health and disease
}

\author{
Marko Kreft ${ }^{1,2 *}$ \\ ${ }^{1}$ Department of Biology, Biotechnical Faculty, University of Ljubljana, Večna pot 111, 1000 Ljubljana, Slovenia \\ ${ }^{2}$ LN-MCP, Institute of Pathophysiology, Faculty of Medicine, University of Ljubljana, Zaloška 4, 1000 Ljubljana, Slovenia E \\ Celica Biomedical, Tehnološki Park 24, 1000 Ljubljana, Slovenia
}

\section{Abstract}

Buckwheat (Fagopyrum esculentum Moench, F. tataricum Gaertner) groats and flour have been established globally as nutritional foods because of their high levels of proteins, polyphenols and minerals. In some regions, buckwheat herb is used as a functional food. In the present study, reports of in vitro studies, preclinical and clinical trials dealing with the effect of buckwheat and its metabolites were reviewed. There are numerous reports of potential health benefits of consuming buckwheat, which may be in the form of food, dietary supplements, home remedies or possibly pharmaceutical drugs; however, adverse effects, including those resulting from contamination, must be considered. There are reports of antioxidative activity of buckwheat, which contains high levels of rutin and quercetin. On the other hand, both cytotoxic and antigenotoxic effects have been shown. Reduction of hyperlipidaemia, reduction of blood pressure and improved weight regulation have been suggested. Consuming buckwheat may have a beneficial effect on diabetes, since lower postprandial blood glucose and insulin response have been reported. In addition, buckwheat metabolites, such as rutin, may have intrinsic protective effects in preserving insulin signalling. Rutin has also been suggested to have potential therapeutic applications for the treatment of Alzheimer's disease. The literature indicates that buckwheat is safe to consume and may have various beneficial effects on human health.

Key words: Buckwheat: Rutin: Adverse effects: Flavonoids: Tartary buckwheat

\section{Introduction}

Two types of buckwheat are used globally: common buckwheat (Fagopyrum esculentum Moench) and Tartary buckwheat ( $F$. tataricum Gaertner). Buckwheat groats and flour have been established as nutritional foods because of their high levels of proteins, rutin, quercetin and minerals ${ }^{(1,2)}$, such as $\mathrm{Se}^{(3)}$. In Europe, buckwheat bread is gaining significance due to its nutritional properties, antioxidant capacity and the possibility of preparing gluten-free bread ${ }^{(4)}$. Recently, buckwheat herb was suggested as a functional food. Milled dried plants may be added as colorant to pasta and other products ${ }^{(5)}$. There are numerous reports of potential health benefits of consuming buckwheat, which may be in a form of food, dietary supplements, home remedies or possibly pharmaceutical drugs. Safety of any food and drugs is of great importance. Recently, a report of severe adverse effect of taking buckwheat tablets was published $^{(6)}$. The authors reported five cases of new-onset polyneuropathy with dyskinesia induced by composite tablets of black tea and Tartary buckwheat used as a hypoglycaemic food supplement. The diagnosed polyneuropathy was relatively rare but severe; for this the present review of known potential health effects of buckwheat products is instrumental to assess the safety of using buckwheat products. First, it is important to note that the medical history of the affected patients revealed that all took tablets from the same batch ${ }^{(6)}$. This makes a strong assumption that contamination may have been the cause of reported acute symptoms, which developed quickly after taking this drug and ceased quickly after withdrawing from taking the tablets. The majority of patients had numbness and weakness of the limbs, paraesthesias, hoarseness and bladder dysfunction; one had either shortness of breath, dysphagia or facial paralysis. No heavy metal or other toxic contaminants were found in the tablet. This may indicate that some highly toxic contaminants present in low quantities were missed by the analyses ${ }^{(6)}$.

The present review addresses known potential health-related effects of buckwheat products. This topic is especially important in view of recent increased public interest in buckwheat (Fig. 1).

\section{Adverse effects as a result of contamination of herbal medicinal products}

The safety and quality of medicinal plant materials and herbal medicinal products are a major concern for health authorities and the public ${ }^{(7)}$. However, numerous adverse effects have been found as a result of adulteration or contamination of herbal medicinal products, such as agranulocytosis, meningitis, organ failure, perinatal stroke and heavy metal poisoning ${ }^{(8)}$. Reports include neurological adverse effects such as paraesthesia and seizures ${ }^{(9)}$. Unfortunately, the data are largely anecdotal. Plant products may be susceptible to attack by pathogenic, often mycotoxigenic, fungi with consequent increase of mycotoxins. Aspergillus flavus may produce aflatoxin B1 (AFB1), the most carcinogenic compound of fungal

* Corresponding author: Marko Kreft, marko.kreft@bf.uni-lj.si 


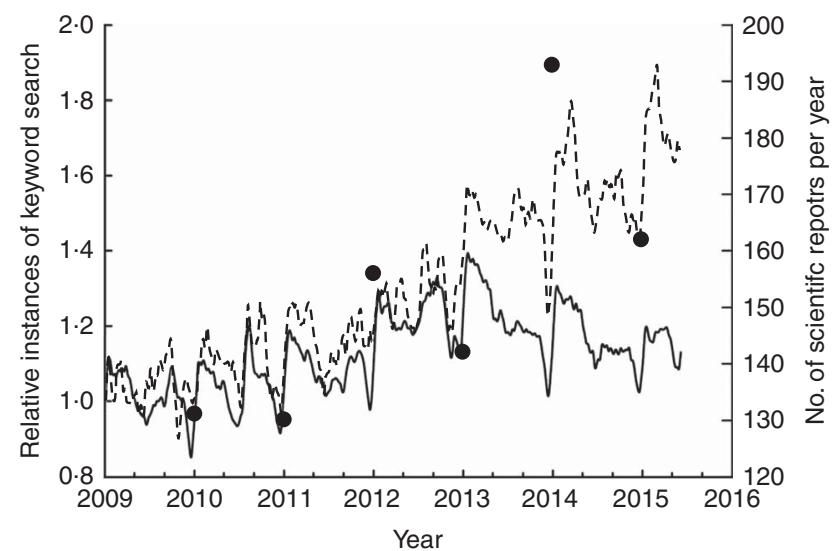

Fig. 1. Increase in public interest in buckwheat. Relative instances of the keyword 'buckwheat' (---) have increased in the last 3 years compared with the keyword 'wheat' (-). Data were taken from Google Trends, which provides an index of the relative volume of search queries conducted through Google. Similarly, an increase in the number of publications on buckwheat $(\bullet)$, indexed in the Web of Science (Thomson Reuters), is noticeable.

origin. Seeds of $F$. tataricum are less susceptible to A. flavus infection compared with $F$. esculentum ${ }^{(10)}$.

Neuropathy described after taking buckwheat tablets ${ }^{(6)}$ may be attributed to contamination with other herbs such as Psychotria rubra ${ }^{(11)}$. Another example of a neurotoxic plant is hemlock (Conium maculatum), which contain piperidine alkaloids, and was probably the cause of death of Socrates ${ }^{(12)}$. Plants from the genus Senecio (Compositae), which contain hepatotoxic pyrrolizidine alkaloids, are a common cause of poisoning with herbal products $^{(13)}$. Chronic toxicity was found in daily doses of pyrrolizidine alkaloids as low as $25 \mu \mathrm{g}^{(14)}$. Botulinum toxins from the bacterium Clostridium botulinum are the most potent toxins, with the lethal dose for an individual by the oral route being $30 \mathrm{ng}^{(15)}$. Clostridia should be absent in all herbal materials, preparations and finished herbal products, as recommended by Annex 5 of WHO guidelines ${ }^{(7)}$. Foods that are fermented and consumed without cooking pose a substantial risk: first, because Clostridia are obligate anaerobes; second, the toxin is degraded by cooking ${ }^{(16)}$. The clinical syndrome of botulism includes symmetrical cranial nerve palsies and flaccid paralysis. This may manifest as an expressionless face, dysphagia, dry mouth, shortness of breath ${ }^{(16,17)}$ and paraesthesia ${ }^{(18)}$. The signs of botulism resemble some signs described in poisoning with buckwheat product $^{(6)}$. Clostridium spp. bacteria have been previously discovered in traditional Chinese herbal medicines, such as Xiyangshen root and Dangshen root ${ }^{(19)}$. Other than possible contaminants, adverse effects may also be due to plant metabolites, naturally present in food and plant products. Here the current literature to elucidate if there is any previous indication that peripheral nerve damage could appear in patients taking buckwheat is reviewed ${ }^{(6)}$. Bibliographic data, analysed in the year 2015, are summarised in Tables 1, 2 and 3.

\section{Phenolic metabolites in buckwheat}

Buckwheat is mainly grown for the production of seeds ${ }^{(20)}$. It is an important functional food, rich in vitamins, essential amino acids and phenolic compounds ${ }^{(21)}$. The content of rutin in
Tartary buckwheat herb is as high as $3 \%$ dry weight, and up to $1.7 \%$ in seeds ${ }^{(22)}$. In common buckwheat milling products rutin content is two orders of magnitude less than in Tartary buckwheat seeds and is highly variable (from 19 to $160 \mathrm{mg} / \mathrm{kg}$ in different flour fractions and $480 \mathrm{mg} / \mathrm{kg}$ in bran) ${ }^{(23)}$. In milling fractions darker colour was also correlated with higher protein and minerals content ${ }^{(24)}$. This variability indicates that rutin and nutrients are not equally distributed in the seed, and is attributed to specific seed morphology ${ }^{(25,26)}$.

Therapeutic doses of rutin have been estimated to be between 180 and $350 \mathrm{mg}^{(27)}$. Thus, the daily intake of $100 \mathrm{~g}$ of buckwheat flour or bran in food would cover $10 \%$ of the therapeutic dose. This contributes to average doses of flavonols and flavons otherwise consumed by at least 2 -fold ${ }^{(28)}$.

The composition and differential content of phenolic compounds in seeds of common buckwheat were recently analysed $^{(29)}$. The list of flavonoids, including rutin, is shown in Table 4 . The most detected hydroxycinnamic acids in seeds are caffeic and chlorogenic acid derivatives ${ }^{(29)}$.

From Tartary buckwheat ( $F$. tataricum) grains a preparative separation successfully purified five flavonoids: quercetin, kaempferol, quercetin 3-O-rutinoside-3'-O- $\beta$-glucopyranoside, rutin and kaempferol 3-rutinoside ${ }^{(30)}$ (Fig. 2). Flavonoid metabolism is related to responses to UVB radiation ${ }^{(31)}$. Recently, a new Tartary buckwheat cultivar, 'Manten-Kirari', has been developed, whose grains contain only trace amounts of rutinosidase and lack bitterness. This is a promising variety for preparing non-bitter, rutin-rich foods ${ }^{(32)}$. The bread-baking procedure using Tartary buckwheat has an impact on rutin, quercetin and polyphenol concentration and antioxidant activity. Rutin concentration during the bread-baking process decreases, while the concentration of quercetin remains stable ${ }^{(33)}$. Similarly, there is much less rutin in noodles compared with flour made from buckwheat ${ }^{(34)}$.

A much higher rutin level than in seeds is found in fresh buckwheat shoots, which are consumed as a salad or cooked ${ }^{(35)}$. The buckwheat plant has the highest concentration of rutin and epicatechin in the leaves and flowers ${ }^{(36)}$, depending on UV irradiation $^{(37)}$. Interestingly, shoots grown from seeds soaked in selenite or selenate solution had higher total flavonoids content compared with soaking seeds in water ${ }^{(38)}$. Additionally to flavonoids, found in seeds, common buckwheat sprouts also contain vitexin, isovitexin and quercetin-3-O-robinobioside ${ }^{(39)}$.

It is important to note that before absorption, dietary phenolic compounds may be transformed in the small intestine by digestive enzymes and in the colon by the intestinal microbiota system $^{(40)}$. For example, rutin may be converted to quercetin, depending on its concentration and composition of the gut microflora ${ }^{(41)}$. Although quercetin is metabolised preferentially to carbon dioxide, the biological half-life is very long, ranging from 20 to $72 \mathrm{~h}^{(42)}$. Furthermore, the absorption of quercetin taken orally is surprisingly high, ranging from 36 to $53 \%^{(42)}$, but relatively slow, since it takes $6 \mathrm{~h}$ for the plasma concentration to steadily reach the peak concentration ${ }^{(43,44)}$.

\section{Other metabolites of buckwheat}

In addition, buckwheat sprouts contain naphthodianthrone fagopyrins that can cause photosensitisation ${ }^{(45,46)}$, manifested 
Table 1. In vitro tests of buckwheat activity and activity of its metabolites

\begin{tabular}{|c|c|c|c|c|}
\hline Compound & Dose & Test used & Main effect & Reference \\
\hline Common buckwheat water extract & $1 \mathrm{mg} / \mathrm{ml}$ & $\begin{array}{l}\text { In vitro human digestion model and } \\
\text { antioxidant activity of lipids in mouse } \\
\text { brain }\end{array}$ & Increase in antioxidative activity & Hur et al. ${ }^{(54)}$ \\
\hline $\begin{array}{l}\text { Quercetin, isoquercetin and rutin from } \\
\text { Tartary buckwheat seeds and bran }\end{array}$ & $12 \cdot 5-100 \mu \mathrm{M}$ & $\begin{array}{l}\text { Cytotoxicity and antioxidant activity on } \\
\text { human hepatoma cell line HepG2 }\end{array}$ & $\begin{array}{l}\text { Quercetin exhibited cytotoxic effects via the } \\
\text { production of reactive oxygen species. Up- } \\
\text { regulation of p53 and p21, and down- } \\
\text { regulation of cyclin D1, Cdk2 and Cdk7 }\end{array}$ & Li et al. ${ }^{(55)}$ \\
\hline $\begin{array}{l}\text { Methanol extracts of common and } \\
\text { Tartary buckwheat }\end{array}$ & $0.1 \mu \mathrm{M}$-rutin, $2.86 \mu \mathrm{M}$-quercetin & $\begin{array}{l}\text { Induced DNA damage in human hepatoma } \\
\text { cell line (HepG2), comet assay }\end{array}$ & Antigenotoxic effect & $\begin{array}{l}\text { Vogrinčič } \\
\text { et al. }{ }^{(57)}\end{array}$ \\
\hline $\begin{array}{l}70 \% \text { aqueous methanol extract of } \\
\text { common buckwheat }\end{array}$ & 0.4 to $20 \mathrm{mg}$ buckwheat $/ \mathrm{ml}$ & $\begin{array}{l}\text { Radical-scavenging activity against DPPH } \\
\text { free radical, TEAC and ORAC assay }\end{array}$ & $\begin{array}{l}\text { Increase of antioxidant activities after } 36 \mathrm{~h} \text { of } \\
\text { seed germination }\end{array}$ & Zhang et al. ${ }^{(59)}$ \\
\hline $\begin{array}{l}\text { Ethanol extracts of Tartary and common } \\
\text { buckwheat sprouts }\end{array}$ & $2.5 \mathrm{mg} / \mathrm{ml}$ of sprouts & $\begin{array}{l}\text { Radical-scavenging activity against DPPH } \\
\text { free radical, ferrous ion-chelating } \\
\text { capability, antioxidative capability on } \\
\text { lecithin lipid micelles }\end{array}$ & $\begin{array}{l}\text { Tartary buckwheat sprouts possess higher } \\
\text { reducing power, free radical-scavenging } \\
\text { activity, and superoxide anion-scavenging } \\
\text { activity than common buckwheat sprouts }\end{array}$ & Lin et al. ${ }^{(62)}$ \\
\hline $\begin{array}{l}60 \% \text { aqueous ethanol extracts from } \\
\text { Tartary buckwheat sprouts }\end{array}$ & $\begin{array}{l}\text { Results expressed as } \mu \text { mol Trolox } \\
\text { equivalents per g dry weight }\end{array}$ & $\begin{array}{l}\text { Scavenge effects of DPPH, ABTS and } \\
\text { superoxide free radicals }\end{array}$ & $\begin{array}{l}\text { Elevated antioxidant activities during } \\
\text { germination are related to increases in } \\
\text { vitamin } \mathrm{C} \text {, total flavonoids and rutin, but not } \\
\text { vitamin } \mathrm{E} \text { and quercetin }\end{array}$ & Zhou et al. ${ }^{(64)}$ \\
\hline $\begin{array}{l}\text { Hot water rutin-free extract of Tartary } \\
\text { buckwheat }\end{array}$ & $\begin{array}{l}\text { Isolates from the acidic fraction } \\
\qquad(0.5-2.5 \mathrm{mg} / \mathrm{ml})\end{array}$ & $\begin{array}{l}\text { Contractile experiment using } \\
\text { Sprague - Dawley rat thoracic aorta rings } \\
\text { contracted by phenylephrine }\end{array}$ & $\begin{array}{l}\text { The acidic fraction of the extract elicited an } \\
\text { endothelium-dependent vasorelaxation effect } \\
\text { via NO/cGMP pathways (EC } \mathrm{EC}_{50} \text { value of } 0.25 \\
\mathrm{mg} / \mathrm{ml} \text { ) }\end{array}$ & Matsui et al. ${ }^{(72)}$ \\
\hline $\begin{array}{l}\text { Hot water rutin-free extract of Tartary } \\
\text { buckwheat }\end{array}$ & $\begin{array}{l}\text { Isolates from the acidic fraction } \\
\quad(0.5-2.5 \mathrm{mg} / \mathrm{ml})\end{array}$ & $\begin{array}{l}\text { Contractile experiment using } \\
\text { Sprague - Dawley rat thoracic aorta rings } \\
\text { contracted by phenylephrine }\end{array}$ & $\begin{array}{l}\text { The acidic fraction of the extract elicited an } \\
\text { endothelium-dependent vasorelaxation effect }\end{array}$ & Ushida et al. ${ }^{(73)}$ \\
\hline Buckwheat rutin isolate & $0.8-8.8 \mathrm{mg} / \mathrm{l}$ rutin & $\begin{array}{l}\text { Measurements of } \mathrm{Ca}^{2+} \text {, calcineurin and } \\
\text { c-fos mRNA expression in cultured } \\
\text { neonatal rat cardiomyocytes }\end{array}$ & $\begin{array}{l}\text { Inhibition of angiotensin II-induced hypertrophy } \\
\text { in cultured neonatal rat cardiomyocytes via } \\
\mathrm{Ca}^{2+}\end{array}$ & Chu et al..$^{(74)}$ \\
\hline Ethanol extract of buckwheat sprouts & $10-500 \mu \mathrm{g}$ extract $/ \mathrm{ml}$ & $\begin{array}{l}\text { Scavenge effects of DPPH, NO, serum } \\
\text { peroxidation and chelating assays }\end{array}$ & $\begin{array}{l}\text { Extract of buckwheat sprouts inhibited serum } \\
\text { oxidation and possessed chelating activity. } \\
\text { Inhibition of pro-inflammatory mediators IL-6 } \\
\text { and TNF-a production in macrophages }\end{array}$ & Karki et al. ${ }^{(81)}$ \\
\hline Rutin & Rutin hydrate $1 \mu \mathrm{g} / \mathrm{ml}$ & $\begin{array}{l}\text { HT22 cell viability test after treatment with } \\
200 \text { mM-ethanol }\end{array}$ & Protection against ethanol neurotoxicity & Song et al. ${ }^{(86)}$ \\
\hline Ethanol extract of buckwheat and rutin & $\begin{array}{l}50-200 \mu \mathrm{g} / \mathrm{ml} \text { extract or } 40 \mu \mathrm{g} / \mathrm{ml} \\
\text { rutin }\end{array}$ & Albumin-fructose glycation assay & Attenuation of protein glycation & Lee et al. ${ }^{(88)}$ \\
\hline Buckwheat bran extracts and rutin & $\begin{array}{l}100 \mu \mathrm{l} \text { of extract } / 500 \mathrm{ml} \text { of enzyme } \\
\text { solution }\end{array}$ & In vitro sucrase enzymic assay & $\begin{array}{l}\text { Buckwheat bran extracts and not pure rutin } \\
\text { inhibits sucrase activity }\end{array}$ & Hosaka et al. ${ }^{(90)}$ \\
\hline Rutin & $0.1-10 \mu \mathrm{m}$ & $\begin{array}{l}\text { RIN-m5F rat insulinoma pancreatic } \beta \text {-cells, } \\
\text { ATP detection assay and insulin secretion } \\
\text { detection }\end{array}$ & $\begin{array}{l}\text { Attenuate the induced glucotoxicity in } \beta \text {-cells by } \\
\text { stimulating insulin receptor substrate } 2 \\
\text { signalling }\end{array}$ & Cai \& $\operatorname{Lin}^{(92)}$ \\
\hline
\end{tabular}

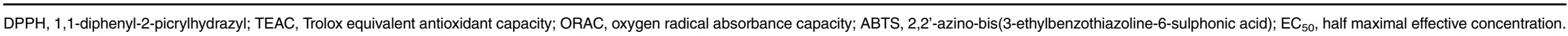


Table 2. Main published preclinical trials dealing with the effect of buckwheat and its metabolites on experimental animals

\begin{tabular}{|c|c|c|c|c|c|c|}
\hline Compound & Dose & Model animal & Study population & Study design & Main outcome & Reference \\
\hline $\begin{array}{l}\text { Ethanol extracts of } \\
\text { Tartary and common } \\
\text { buckwheat sprouts }\end{array}$ & $2.5 \mathrm{mg} / \mathrm{ml}$ of sprouts & Syrian hamsters & Thirty-six animals & $\begin{array}{l}\text { Six groups fed for } 28 \mathrm{~d} \text { : control meal, high fat, plus } \\
2.5 \% \text { or } 25 \% \text { of buckwheat seeds, plus } 2.5 \% \text { or } \\
25 \% \text { of sprouts }\end{array}$ & $\begin{array}{l}\text { Buckwheat meals reduced total } \\
\text { cholesterol level and serum TAG } \\
\text { levels }\end{array}$ & Lin et al. ${ }^{(62)}$ \\
\hline $\begin{array}{l}\text { Raw common buckwheat } \\
\text { extract and germinated } \\
\text { buckwheat extract }\end{array}$ & $300-600 \mathrm{mg} / \mathrm{kg}$ & $\begin{array}{l}\text { Spontaneously } \\
\text { hypertensive rats } \\
\text { and normotensive } \\
\text { Wistar-Kyoto rats }\end{array}$ & Sixty animals & $\begin{array}{l}\text { Six groups fed for } 5 \text { weeks: water, } 300 \text { and } 600 \mathrm{mg} / \mathrm{kg} \\
\text { of raw and germinated extract-treated groups, and } \\
2.5 \mathrm{mg} / \mathrm{kg} \text { captopril-treated (positive control) group }\end{array}$ & $\begin{array}{l}\text { Reduced oxidative damage in aortic } \\
\text { endothelial cells by lowering } \\
\text { nitrotyrosine immunoreactivity }\end{array}$ & Kim et al. ${ }^{(63)}$ \\
\hline $\begin{array}{l}\text { Tartary and common } \\
\text { buckwheat protein } \\
\text { product }\end{array}$ & $\begin{array}{l}\text { Buckwheat protein product } \\
\text { (Tartary: } 1710 \mathrm{mg} \\
\text { quercetin } / 100 \mathrm{~g} \text { ), } \\
\text { (common: } 5.4 \mathrm{mg} \\
\text { quercetin } / 100 \mathrm{~g} \text { ) }\end{array}$ & $\begin{array}{l}\text { Male Sprague- } \\
\text { Dawley rats and } \\
\text { male ddY mice }\end{array}$ & $\begin{array}{l}\text { Three groups of } \\
\text { eight or nine } \\
\text { rats, three } \\
\text { groups of nine } \\
\text { mice }\end{array}$ & $\begin{array}{l}\text { Three groups of rats and mice were given } \\
\text { experimental diets. Cholesterol and sodium cholate } \\
\text { were added to the diets including casein, common } \\
\text { or Tartary buckwheat protein extract }\end{array}$ & $\begin{array}{l}\text { Reductions in serum cholesterol, in } \\
\text { rats, enhanced excretion of faecal } \\
\text { neutral sterols. Reduction in the } \\
\text { lithogenic index }\end{array}$ & Tomotake et al. ${ }^{(68)}$ \\
\hline $\begin{array}{l}70 \% \text { ethanol extracts of } \\
\text { germinated common } \\
\text { buckwheat seeds }\end{array}$ & $\begin{array}{l}100-200 \mathrm{mg} \text { germinated } \\
\text { buckwheat extract/kg } \\
\text { body weight daily }\end{array}$ & C57BL/6 male mice & Thirty animals & $\begin{array}{l}\text { Control high-fat diet group and two germinated } \\
\text { buckwheat extract-fed groups. } 100 \mathrm{mg} \text { and } 200 \mathrm{mg} \\
\text { germinated buckwheat extract/kg body weight daily }\end{array}$ & $\begin{array}{l}\text { Increased concentrations of serum } \\
\text { HDL-cholesterol. Down-regulation of } \\
\text { mRNA expressions of PPARY and C/ } \\
\text { EBPa in hepatocytes }\end{array}$ & Choi et al. ${ }^{(69)}$ \\
\hline $\begin{array}{l}\text { Dry Tartary buckwheat } \\
\text { sprouts, used in the } \\
\text { production of pasta }\end{array}$ & $\begin{array}{l}5 \mathrm{~g} \text { of pasta per rat per d } \\
\text { (contained } 30 \% \text { of Tartary } \\
\text { sprouts) }\end{array}$ & $\begin{array}{l}\text { Spontaneously } \\
\text { hypertensive rats } \\
\text { normotensive } \\
\text { counterpart, } \\
\text { Wistar-Kyoto rats }\end{array}$ & Twenty animals & $\begin{array}{l}\text { Two strains of rats were randomly divided into two diet } \\
\text { groups: durum wheat flour pasta and Tartary } \\
\text { buckwheat sprouts }\end{array}$ & $\begin{array}{l}\text { Higher plasma levels of vasodilators, a } \\
\text { lower level of the vasoconstrictor, } \\
\text { and improved antioxidant capacity }\end{array}$ & Merendino et al. ${ }^{(71)}$ \\
\hline $\begin{array}{l}\text { Tartary flour digested with } \\
\text { pepsin, chymotrypsin } \\
\text { and trypsin }\end{array}$ & $\begin{array}{l}100 \mathrm{mg} \text { of buckwheat digest } \\
\text { per kg body weight }\end{array}$ & $\begin{array}{l}\text { Spontaneously } \\
\text { hypertensive rats }\end{array}$ & Ten animals & $\begin{array}{l}\text { Two groups: one fed a diet with the Tartary buckwheat } \\
\text { digest }\end{array}$ & $\begin{array}{l}\text { Tartary buckwheat protein and not rutin } \\
\text { exhibit angiotensin I-converting } \\
\text { enzyme inhibition }\end{array}$ & Li et al. ${ }^{(75)}$ \\
\hline $\begin{array}{l}\text { Common buckwheat flour } \\
\text { and wheat germ }\end{array}$ & $\begin{array}{l}20 \%(w / w) \text { of wheat germ } \\
\text { and buckwheat flour } \\
\text { relative to control diet }\end{array}$ & $\begin{array}{l}\text { Female ICR/CD-1 } \\
\text { mice }\end{array}$ & $\begin{array}{l}260 \text { animals } \\
\text { screened, } \\
\text { eighty-eight } \\
\text { used }\end{array}$ & $\begin{array}{l}\text { The non-prematurely ageing mice as control group, } \\
\text { prematurely ageing mice randomly divided into } \\
\text { control group }(n 26) \text { and wheat germ and buckwheat } \\
\text { flour groups }\end{array}$ & $\begin{array}{l}\text { Prematurely ageing mice that received } \\
\text { cereal buckwheat showed improved } \\
\text { parameters of innate and acquired } \\
\text { immune responses }\end{array}$ & Alvarez et al. ${ }^{(76)}$ \\
\hline $\begin{array}{l}75 \% \text { ethanol extracts } \\
\text { from Tartary } \\
\text { buckwheat }\end{array}$ & $\begin{array}{l}\text { Extract contained } 228.8 \mathrm{mg} / \mathrm{g} \\
\text { of rutin and } 58.6 \mathrm{mg} / \mathrm{g} \text { of } \\
\text { quercetin }\end{array}$ & $\begin{array}{l}\text { Male C57BL/6 mice } \\
\text { and male } \\
\text { Sprague-Dawley } \\
\text { rats }\end{array}$ & $\begin{array}{l}\text { Six groups of six } \\
\text { rats and six } \\
\text { groups of six } \\
\text { mice }\end{array}$ & $\begin{array}{l}\text { Increase of liver enzymes in serum was monitored in } \\
\text { the ethanol-and carbon tetrachloride-induced } \\
\text { animals. Antioxidant enzyme activities were also } \\
\text { monitored }\end{array}$ & $\begin{array}{l}\text { Hepatoprotection via promoting } \\
\text { antioxidative and anti-inflammatory } \\
\text { properties against oxidative liver } \\
\text { damage }\end{array}$ & Lee et al. ${ }^{(82)}$ \\
\hline $\begin{array}{l}\text { Common buckwheat } \\
\text { protein extract }\end{array}$ & $38.1 \%$ of the daily diet & $\begin{array}{l}\text { Female Sprague- } \\
\text { Dawley rats }\end{array}$ & $\begin{array}{l}\text { Two groups of } \\
\text { twenty animals }\end{array}$ & $\begin{array}{l}\text { The 7,12-dimethylbenz anthracene-treated rats } \\
\text { examined for palpable mammary tumours and } \\
\text { serum level of oestradiol was measured }\end{array}$ & $\begin{array}{l}\text { Retardation of the development of } \\
\text { mammary tumour in rats, correlated } \\
\text { with lower serum oestradiol }\end{array}$ & Kayashita et al. ${ }^{(83)}$ \\
\hline $\begin{array}{l}\text { Rutin and } n \text {-butanol } \\
\text { extracted from Tartary } \\
\text { buckwheat }\end{array}$ & $\begin{array}{l}100 \mathrm{mg} / \mathrm{kg} \mathrm{per} \mathrm{d} \text { of rutin; } \\
100-200 \mathrm{mg} / \mathrm{kg} \text { per } \mathrm{d} \text { of } \\
n \text {-butanol }\end{array}$ & Male ICR mice & $\begin{array}{l}\text { Five groups of five } \\
\text { animals }\end{array}$ & $\begin{array}{l}n \text {-Butanol- and rutin-administered animals (model of } \\
\text { amyloid } \beta \text {-induced Alzheimer's disease) assessed } \\
\text { using the T-maze, object recognition, and Morris } \\
\text { water maze tests }\end{array}$ & $\begin{array}{l}\text { Administration of buckwheat extracts } \\
\text { alleviated induced cognitive } \\
\text { impairments }\end{array}$ & Choi et al. ${ }^{(85)}$ \\
\hline Rutin & $25-100 \mathrm{mg} / \mathrm{kg}$ per d & Male Wistar rats & $\begin{array}{l}\text { Six groups of } \\
\text { animals }\end{array}$ & $\begin{array}{l}\text { Haloperidol-induced orofacial dyskinesia evaluated by } \\
\text { behavioural tests (orofacial dyskinetic movements, } \\
\text { stereotypic rearing, locomotor activity, percent } \\
\text { retention) }\end{array}$ & $\begin{array}{l}\text { Pretreatment with rutin reversed } \\
\text { behavioural changes induced by } \\
\text { haloperidol }\end{array}$ & Bishnoi et al. ${ }^{(87)}$ \\
\hline $\begin{array}{l}\text { Ethanol extract of } \\
\text { buckwheat, rutin and } \\
\text { quercetin }\end{array}$ & $\begin{array}{l}\text { Extract }(100 \mu \mathrm{g} / \mathrm{ml}, 50 \mathrm{mg} / \\
\mathrm{kg}), \text { quercetin }(6 \mu \mathrm{g} / \mathrm{ml} ; \\
3 \mathrm{mg} / \mathrm{kg}) \text {, and rutin } \\
(23 \mu \mathrm{g} / \mathrm{ml} ; 11.5 \mathrm{mg} / \mathrm{kg})\end{array}$ & C57BL/6 mice & $\begin{array}{l}\text { Six groups of } \\
\text { twelve animals }\end{array}$ & $\begin{array}{l}\text { Oral glucose tolerance test and assay for blood } \\
\text { glucose and insulin }\end{array}$ & $\begin{array}{l}\text { Inhibited increases in blood glucose } \\
\text { and insulin levels induced by } \\
\text { fructose-rich diet }\end{array}$ & Lee et al. ${ }^{(89)}$ \\
\hline $\begin{array}{l}\text { Buckwheat leaf and } \\
\text { flower }\end{array}$ & $5 \%$ buckwheat in the diet & Male Wistar rats & $\begin{array}{l}\text { Forty animals in } \\
\text { five groups }\end{array}$ & $\begin{array}{l}\text { Rats fed a high-fat diet were analysed for weight gain, } \\
\text { plasma lipid levels and differential plasma fatty acid } \\
\text { concentration }\end{array}$ & $\begin{array}{l}\text { Reduction of weight gain, plasma lipid } \\
\text { concentrations and atherogenic } \\
\text { index }\end{array}$ & $\begin{array}{l}\text { Đurendić-Brenesel } \\
\text { et al. }\end{array}$ \\
\hline
\end{tabular}

ICR, Imprinting Control Region. 
Table 4. Flavonoids from common buckwheat seeds ${ }^{(29)}$

Catechin

Epiafzelechin-epicatechin

Epicatechin

Isoorientin

Kaempferol-3-rutinoside

Kaempferol-hexoside

Orientin

Procyanidin B2 dimetilygallate

Procyanidin dimer (catechin-catechin)

Procyanidin dimer monogalate

Procyanidin tetramer isomer (four epicatechin units)

Procyanidin trimer 1

Procyanidin trimer 2 (three epicatechin units)

Procyanidin trimer 3 [epiafzelechin-(4-8)-epicatechin-

O-(3,4-dimethyl)-gallate]

Quercetin-3-galactoside (hyperin)

Quercetin-3-glucoside (isoquercitrin)

Quercetin-3-rhamnoside (quercitrin)

Quercetin-3-rutinoside (rutin)

Quercetin-hexoside gallate 
<smiles>[R6]c1cc(-c2oc3c([R5])c(O)cc([R4])c3c(=O)c2[R2])cc([R6])c1[R7]</smiles>

Quercetin: $\mathrm{R} 1=\mathrm{OH}, \mathrm{R} 2=\mathrm{OH}, \mathrm{R} 3=\mathrm{H}, \mathrm{R} 4=\mathrm{OH}, \mathrm{R} 5=\mathrm{H}, \mathrm{R} 6=\mathrm{OH}$ Quercitrin: R1=OH, R2=rhamnose, R3=H, R4=OH, R5=H, R6=OH Rutin: R1=OH, R2=glucorhamnose, R3=H, R4=OH, R5=H, R6=OH Isoquercitrin: $\mathrm{R} 1=\mathrm{OH}, \mathrm{R} 2=$ glucose, $\mathrm{R} 3=\mathrm{H}, \mathrm{R} 4=\mathrm{OH}, \mathrm{R} 5=\mathrm{H}, \mathrm{R} 6=\mathrm{OH}$ Kaempferol: $\mathrm{R} 1=\mathrm{OH}, \mathrm{R} 2=\mathrm{OH}, \mathrm{R} 3=\mathrm{H}, \mathrm{R} 4=\mathrm{OH}, \mathrm{R} 5=\mathrm{H}, \mathrm{R} 6=\mathrm{H}$ Orientin: $\mathrm{R} 1=\mathrm{OH}, \mathrm{R} 2=\mathrm{H}, \mathrm{R} 3=\mathrm{H}, \mathrm{R} 4=\mathrm{OH}, \mathrm{R} 5=$ glucose, $\mathrm{R} 6=\mathrm{OH}$ Vitexin: $\mathrm{R} 1=\mathrm{OH}, \mathrm{R} 2=\mathrm{H}, \mathrm{R} 3=\mathrm{H}, \mathrm{R} 4=\mathrm{OH}, \mathrm{R} 5=$ glucose, $\mathrm{R} 6=\mathrm{H}$

Catechin<smiles>Oc1cc(O)c2c(c1)OC(c1ccc(O)c(O)c1)C(O)C2</smiles>

Fig. 2. Structures of main flavonoids found in buckwheat. Flavones have $A, C$ and $B$ ring structures, with substitutions as indicated at B4' (R1), C3 (R2), B5 (R3), A5 (R4), A8 (R5) and B3' (R6).

enhancement of the antioxidant activities of germinated buckwheat and may be used as a promising functional food ${ }^{(59)}$. Buckwheat sprouts are suggested as a new vegetable ${ }^{(60)}$. The highest total phenols in buckwheat sprouts of germinated soaked buckwheat seeds is at day $6^{(61)}$ or day $8^{(62)}$. Specifically, compared with buckwheat seeds, the sprouts contain relatively large amounts of rutin ${ }^{(48,60)}$.

Common buckwheat and Tartary buckwheat sprouts have different antioxidant activities. It has been shown that the ethanol extracts of Tartary buckwheat sprouts have higher reducing power, free radical scavenging activity, and superoxide anion scavenging activity than those of common buckwheat sprouts, possibly because of their higher rutin and quercetin content ${ }^{(62)}$. Treatment with raw common buckwheat extract and germinated buckwheat extract reduced oxidative damage in aortic endothelial cells by lowering nitrotyrosine immunoreactivity, which suggests an antihypertensive effect and may protect arterial endothelial cells from oxidative stress $^{(63)}$. In Tartary buckwheat, the compounds which play a key role in the elevated antioxidant activities during germination consisted of vitamin $\mathrm{C}$, total flavonoids and rutin, but not vitamin $\mathrm{E}$ and quercetin ${ }^{(64)}$.

\section{CVD, hypertension and plasma cholesterol}

Food rich in polyphenols possess cardiovascular protective properties $^{(65)}$, and antihypertensive properties ${ }^{(66)}$. Specifically, buckwheat products reduce the serum levels of myeloperoxidase and cholesterol ${ }^{(67)}$. The reduction of serum cholesterol by common and Tartary buckwheat protein products is associated with enhanced excretion of faecal neutral sterols bile acids in mice and rats ${ }^{(68)}$. Extract of germinating common buckwheat seeds, administered orally to mice, reduces hepatic TAG and total cholesterol, and down-regulates the expression of adipogenic transcription factors PPAR $\gamma$ and $\mathrm{C} / \mathrm{EBP} \alpha$ in hepatocytes ${ }^{(69)}$. Some earlier studies indicated reduced senile hyperlipidaemia, reduced blood pressure and reduction of weight; however, these trials were without control groups (for a review, see Wieslander \& Norbäck $\left.{ }^{(70)}\right)$.

It has been shown that spontaneously hypertensive rats fed Tartary buckwheat sprouts exhibit higher plasma levels of the endogenous vasodilators bradykinin and NO, a lower level of the vasoconstrictor endothelin-1, and an improved antioxidant capacity, which may collectively reduce hypertension and oxidative stress in vivo ${ }^{(71)}$. A potent vasorelaxant effect was found in the $(+)$-osbeckic acid dimer, which was isolated from rutin-free Tartary buckwheat extract ${ }^{(72)}$. Tartary buckwheat rutin-free extracts exert endothelium-dependent vasorelaxation action in isolated rat aorta rings, probably by NO/cGMP signalling pathways ${ }^{(73)}$. Buckwheat rutin exhibits an inhibitory effect on angiotensin II-induced hypertrophy in cultured neonatal rat cardiomyocytes via $\mathrm{Ca}^{2+}$ antagonism action, thus blocking the calcineurin-dependent signal pathway ${ }^{(74)}$. Tartary buckwheat protein and not rutin exhibit angiotensin I-converting enzyme inhibition. Oral administration of Tartary buckwheat digest has been found to lower the blood pressure of hypertensive rats ${ }^{(75)}$.

\section{Immune system and inflammation}

Dietary supplementation with buckwheat flour appears to have a protective effect on immune cell functions in mice with premature senescence ${ }^{(76)}$. Several parameters of innate immune response were increased: macrophage chemotaxis, phagocytosis, microbicidal activity, natural killer activity, as well as parameters of acquired immune response: lymphoproliferative response to concanavalin A and lipopolysaccharide, and IL-2 release ${ }^{(76)}$.

Flavonoids including quercetin have shown viral inhibition properties such as antiherpetic activity against Herpes simplex virus, types 1 and $2^{(77)}$. A survey on parents of 105 children with upper respiratory tract infections was performed to compare the effects of a single dose of buckwheat honey or honey-flavoured dextromethorphan with no treatment. Significant differences in symptom improvement were detected between treatment groups, with honey consistently scoring the best and no treatment scoring the worst ${ }^{(78)}$. However, it was not yet established if honey in general or buckwheat honey specifically was favourable for the relief of coughing.

Ihme $e t a l .{ }^{(79)}$ investigated the effect of buckwheat herb tea in treating leg oedema in patients with chronic venous insufficiency. Results of a randomised double-blind placebo-controlled clinical trial indicated potential use in patients to prevent the further development of oedema. As importantly, the study on sixty-seven patients confirmed the safety of this treatment ${ }^{(79)}$.

Rutin has potential anti-inflammatory properties ${ }^{(80)}$. It is a potent inhibitor of phorbol-12-myristate 13-acetate (PMA), TNF- $\alpha$, IL- $1 \beta$, and caecal ligation and puncture (CLP)-mediated endothelial cell protein $\mathrm{C}$ receptor shedding ${ }^{(80)}$. Extract of 
buckwheat sprouts was shown to inhibit pro-inflammatory mediators IL-6 and TNF- $\alpha$ production in macrophages ${ }^{(81)}$. Extracts from Tartary buckwheat were shown to exert hepatoprotection via promoting antioxidative and anti-inflammatory properties against oxidative liver damage in mice. This was manifested as inhibiting the increase in serum aspartate transaminase, alanine transaminase and alkaline phosphatase levels in challenged animals ${ }^{(82)}$. A buckwheat protein diet may retard the development of mammary tumours in female rats, which was found to be correlated with lower serum oestradiol ${ }^{(83)}$.

A double-blind cross-over intervention study was conducted to study the effects of common and Tartary buckwheat consumption on mucosal symptoms, i.e. ocular, nasal and throat symptoms; further, headache and tiredness were evaluated $^{(84)}$. Both types of buckwheat had generally positive effects on these symptoms.

\section{Neurological disorders}

It was recently shown that the $n$-butanol fraction and rutin extracted from Tartary buckwheat are protective against and have possible therapeutic applications for the treatment of Alzheimer's disease $^{(85)}$. This was confirmed by studying learning and memory deficits in a mouse model of amyloid $\beta$-induced Alzheimer's disease. Animals' impaired cognition and memory were alleviated by the oral administration of an $n$-butanol fraction and rutin extracted from Tartary buckwheat ${ }^{(85)}$.

Rutin's protective effects against acetaldehyde-based ethanol neurotoxicity have been found. Rutin protects hippocampal neuronal cells against ethanol-induced neurotoxicity by increasing aldehyde dehydrogenase 2 (ALDH2) activity. Its metabolite, acetaldehyde, is critically toxic. ALDH2 metabolises acetaldehyde into non-toxic acetate ${ }^{(86)}$. Rutin was suggested as a protective compound against the haloperidol-induced motor disorder orofacial dyskinesia, resulting from the chronic neuroleptic treatment of schizophrenia ${ }^{(87)}$. Haloperidol induces oxidative damage in all regions of the brain in rats, which was prevented by rutin, which may be a possible therapeutic to treat this motor disorder ${ }^{(87)}$

\section{Weight regulation and diabetes}

Tartary buckwheat is used for the treatment of type 2 diabetes mellitus in Taiwan. It has been shown that the ethanol extract of buckwheat and rutin attenuates protein glycation to lower the generation of advanced glycation endproducts through the suppression of fructosamine and $\alpha$-dicarbonyl compounds; hence it may be used as a protection agent in diabetic patients ${ }^{(88)}$. The ethanol extract of buckwheat, rutin and quercetin improved glucose uptake via promoting Akt phosphorylation and preventing PPAR $\gamma$ degradation in a hepatocyte cell line ${ }^{(89)}$. Buckwheat bran extracts and not pure rutin inhibit sucrase activity in vitro, which may have a beneficial effect on diabetes ${ }^{(90)}$. Similarly, it seems that buckwheat concentrate has insulin-mimetic effects on select protein phosphorylation events in rat hepatoma cells; however, D-chiro-inositol and myoinositol are not probably active components responsible for the observed effects ${ }^{(91)}$. Rutin was found to attenuate the induced glucotoxicity in $\beta$-cells by stimulating insulin receptor substrate 2 signalling in rat pancreatic $\beta$-cells. The intrinsic protective effects of rutin in preserving insulin signalling may lead to novel strategies for the prevention of type 2 diabetes $^{(92)}$.

In healthy subjects consuming bread with buckwheat and wheat flour, lower postprandial blood glucose and insulin response were measured, compared with a group eating wheat bread $^{(93)}$. Proanthocyanidins in buckwheat flour can reduce salivary nitrite to $\mathrm{NO}$ in the stomach. This may improve the activity of the stomach, helping the digestion of ingested foods ${ }^{(94)}$. Proanthocyanidins from persimmon inhibit oxidative stress and the digestive enzymes related to diabetes, such as $\alpha$-amylase and $\alpha$-glucosidase ${ }^{(95)}$.

Buckwheat leaf and flower food supplementation apparently reduces weight gain, plasma lipid concentrations and atherogenic index in rats fed a high-fat diet; buckwheat products are thus suggested for the potential prevention and curing of hyperlipidaemia ${ }^{(96)}$.

\section{Summary}

Numerous reports have shown the potential health benefits of consuming buckwheat, which may be in the form of food, dietary supplements, home remedies or possibly pharmaceutical drugs. There are reports of the antioxidative activity of buckwheat; on the other hand, both cytotoxic and antigenotoxic effects have been shown. Reduction of hyperlipidaemia, reduction of blood pressure and improved weight regulation have been suggested. Consuming buckwheat may have beneficial effect on diabetes. Rutin was also suggested to have potential therapeutic applications for the treatment of Alzheimer's disease. It can be concluded that the literature indicates that buckwheat is safe to consume and may have various beneficial effects on human health.

\section{Acknowledgements}

Valuable comments and the help of Professor Ivan Kreft (Biotechnical Faculty, University of Ljubljana \& Slovenian Forestry Institute) and Professor Samo Kreft (Faculty of Pharmacy, University of Ljubljana) are gratefully acknowledged.

This research received no specific grant from any funding agency, commercial or not-for-profit sectors.

There are no conflicts of interest.

\section{References}

1. Bonafaccia G, Marocchini M \& Kreft I (2003) Composition and technological properties of the flour and bran from common and Tartary buckwheat. Food Chem 80, 9-15.

2. Pongrac P, Vogel-Mikus K, Jeromel L, et al. (2013) Spatially resolved distributions of the mineral elements in the grain of Tartary buckwheat (Fagopyrum tataricum). Food Res Int $\mathbf{5 4}$, $125-131$

3. Kreft I, Mechora S, Germ M, et al. (2013) Impact of selenium on mitochondrial activity in young Tartary buckwheat plants. Plant Physiol Biochem 63, 196-199.

4. Costantini L, Lukšič L, Molinari R, et al. (2014) Development of gluten-free bread using Tartary buckwheat and chia flour rich 
in flavonoids and omega- 3 fatty acids as ingredients. Food Chem 165, 232-240.

5. Kim SL, Soon YK, Hwang JJ, et al. (2001) Development and utilization of buckwheat sprouts as functional vegetables. Fagopyrum 18, 6.

6. Yang F, Yu SY, Wang Y, et al. (2014) Prospective induction of peripheral neuropathy by the use of Tartarian buckwheat. J Neurol Sci 347, 155-158.

7. World Health Organization (2007) WHO Guidelines for Assessing Quality of Herbal Medicines with Reference to Contaminants and Residues. Geneva: WHO.

8. Posadzki P, Watson L \& Ernst E (2013) Contamination and adulteration of herbal medicinal products (HMPs): an overview of systematic reviews. Eur J Clin Pharmacol 69 295-307.

9. Ernst E (2003) Serious psychiatric and neurological adverse effects of herbal medicines - a systematic review. Acta Psychiatr Scand 108, 83-91.

10. Chitarrini G, Nobili C, Pinzari F, et al. (2014) Buckwheat achenes antioxidant profile modulates Aspergillus flavus growth and aflatoxin production. Int J Food Microbiol 189, $1-10$.

11. Mak W, Leung SY, But PPH, et al. (1998) Toxic neuropathy following ingestion of self-collected herbs Psychotira rubra. Neurol J Southeast Asia 3, 41-44.

12. Reynolds $\mathrm{T}$ (2005) Hemlock alkaloids from Socrates to poison aloes. Phytochemistry 66, 1399-1406.

13. Prakash AS, Pereira TN, Reilly PE, et al. (1999) Pyrrolizidine alkaloids in human diet. Mutat Res $\mathbf{4 4 3}, 53-67$.

14. Rasenack R, Müller C, Kleinschmidt M, et al. (2003) Venoocclusive disease in a fetus caused by pyrrolizidine alkaloids of food origin. Fetal Diagn Ther 18, 223-225.

15. Peck MW (2006) Clostridium botulinum and the safety of minimally heated, chilled foods: an emerging issue? J Appl Microbiol 101, 556-570.

16. Sobel J (2005) Botulism. Clin Infect Dis 41, 1167-1173.

17. Varma JK, Katsitadze G, Moiscrafishvili M, et al. (2004) Signs and symptoms predictive of death in patients with foodborne botulism - Republic of Georgia, 1980-2002. Clin Infect Dis 39, 357-362.

18. Hughes JM, Blumenthal JR, Merson MH, et al. (1981) Clinical features of types A and B food-borne botulism. Ann Intern Med 95, 442-445.

19. Ting A, Chow Y \& Tan W (2013) Microbial and heavy metal contamination in commonly consumed traditional Chinese herbal medicines. J Tradit Chin Med 33, 119-124.

20. Wijngaard HH \& Arendt EK (2006) Buckwheat. Cereal Chem 83, 11.

21. Holasova M, Fiedlerova V, Smrcinova H, et al. (2002) Buckwheat - the source of antioxidant activity in functional foods. Food Res Int 35, 207-211.

22. Fabjan N, Rode J, Kosir IJ, et al. (2003) Tartary buckwheat (Fagopyrum tataricum Gaertn.) as a source of dietary rutin and quercitrin. J Agric Food Chem 51, 6452-6455.

23. Kreft S, Knapp M \& Kreft I (1999) Extraction of rutin from buckwheat (Fagopyrum esculentum Moench) seeds and determination by capillary electrophoresis. J Agric Food Chem 47, 4649-4652.

24. Skrabanja V, Kreft I, Golob T, et al. (2004) Nutrient content in buckwheat milling fractions. Cereal Chem 81, 172-176.

25. Kreft M \& Kreft S (1999) Computer aided three-dimensional reconstruction of the buckwheat (Fagopyrum esculentum Moench) seed morphology. Zbk Bioteh Fak Univ Ljubl Kmet 73, 331-336.

26. Kreft S \& Kreft M (2000) Localization and morphology of the buckwheat embryo. Fagopyrum 17, 15-19.
27. Schilcher H, Patz B \& Schimmel KC (1990) Klinische Studie mit einem Phytopharmakon zur Behandlung von Mikrozirkulationsstörungen (Clinical trial with a phytopharmaceutical for the treatment of microcirculatory disorders Ärztezeitschr Naturbeilverf 31, 819-826.

28. Hertog MGL, Holman PCH \& Katan MB (1992) Content of potentially anticancerogenic flavonoids of 28 vegetables and 9 fruits commonly consumed in The Netherlands. J Agric Food Chem 40, 2379-2383.

29. Kiprovski B, Mikulic-Petkovsek M, Slatnar A, et al. (2015) Comparison of phenolic profiles and antioxidant properties of European Fagopyrum esculentum cultivars. Food Chem 185, 41-47.

30. Jiang S, Liu Q, Xie Y, et al. (2015) Separation of five flavonoids from Tartary buckwheat (Fagopyrum tataricum (L.) Gaertn) grains via off-line two dimensional high-speed countercurrent chromatography. Food Chem 186, 153-159.

31. Regvar M, Bukovnik U, Likar M, et al. (2012) UV-B radiation affects flavonoids and fungal colonisation in Fagopyrum esculentum and F. tataricum. Cent Eur J Biol 7, 275-283.

32. Suzuki T, Morishita T, Mukasa Y, et al. (2014) Breeding of 'Manten-Kirari', a non-bitter and trace-rutinosidase variety of Tartary buckwheat (Fagopyrum tataricum Gaertn.). Breed Sci 64, 344-350.

33. Vogrincic M, Timoracka M, Melichacova S, et al. (2010) Degradation of rutin and polyphenols during the preparation of Tartary buckwheat bread. J Agric Food Chem 58, 4883-4887.

34. Kreft I, Fabjan N \& Yasumoto K (2006) Rutin content in buckwheat (Fagopyrum esculentum Moench) food materials and products. Food Chem $\mathbf{9 8}, 508-512$.

35. Kreft I, Chang K-C, Choi YS, et al. (2003) Ethnobotany of Buckwheat. Seoul, Korea: Jinsol Publishing Co.

36. Kalinova J, Triska J \& Vrchotova N (2006) Distribution of vitamin E, squalene, epicatechin, and rutin in common buckwheat plants (Fagopyrum esculentum Moench). J Agric Food Chem 54, 5330-5335.

37. Kreft S, Strukelj B, Gaberscik A, et al. (2002) Rutin in buckwheat herbs grown at different UV-B radiation levels: comparison of two UV spectrophotometric and an HPLC method. J Exp Bot 53, 1801-1804.

38. Ozbolt L, Kreft S, Kreft I, et al. (2008) Distribution of selenium and phenolics in buckwheat plants grown from seeds soaked in Se solution and under different levels of UV-B radiation. Food Chem 110, 691-696.

39. Nam TG, Lee SM, Park JH, et al. (2015) Flavonoid analysis of buckwheat sprouts. Food Chem 170, 97-101.

40. Selma MV, Espín JC \& Tomás-Barberán FA (2009) Interaction between phenolics and gut microbiota: role in human health. J Agric Food Chem 57, 6485-6501.

41. Rechner AR, Smith MA, Kuhnle G, et al. (2004) Colonic metabolism of dietary polyphenols: influence of structure on microbial fermentation products. Free Radic Biol Med 36, 212-225.

42. Walle T, Walle UK \& Halushka PV (2001) Carbon dioxide is the major metabolite of quercetin in humans. J Nutr $\mathbf{1 3 1}$, $2648-2652$.

43. Murota K, Matsuda N, Kashino Y, et al. (2010) $\alpha$-Oligoglucosylation of a sugar moiety enhances the bioavailability of quercetin glucosides in humans. Arch Biochem Biophys 501, 91-97.

44. Erlund I, Kosonen T, Alfthan G, et al. (2000) Pharmacokinetics of quercetin from quercetin aglycone and rutin in healthy volunteers. Eur J Clin Pharmacol 56, 545-553.

45. Benkovic E, Zigon D, Friedrich $\mathrm{M}$, et al. (2014) Isolation, analysis and structures of phototoxic fagopyrins from buckwheat. Food Chem 143, 432-439. 
46. Tavčar Benković E \& Kreft S (2015) Fagopyrins and protofagopyrins: detection, analysis, and potential phototoxicity in buckwheat. J Agric Food Chem 63, 5715-5724.

47. Stojilkovski K, Glavac N, Kreft S, et al. (2013) Fagopyrin and flavonoid contents in common, Tartary, and cymosum buckwheat. J Food Compos Anal 32, 126-130.

48. Kreft S, Janeš D \& Kreft I (2013) The content of fagopyrin and polyphenols in common and Tartary buckwheat sprouts. Acta Pharm 63, 553-560.

49. Janeš D \& Kreft S (2008) Salicylaldehyde is a characteristic aroma component of buckwheat groats. Food Chem 109, 293-298.

50. Janeš D, Prosen H, Kreft I, et al. (2010) Aroma compounds in buckwheat (Fagopyrum esculentum Moench) groats, flour, bran, and husk. Cereal Chem 87, 141-143.

51. Prosen H, Kokalj M, Janeš D, et al. (2010) Comparison of isolation methods for the determination of buckwheat volatile compounds. Food Chem 121, 298-306.

52. Janeš D, Kantar D, Kreft S, et al. (2009) Identification of buckwheat (Fagopyrum esculentum Moench) aroma compounds with GC-MS. Food Chem 112, 120-124.

53. Janeš D, Prosen H \& Kreft S (2012) Identification and quantification of aroma compounds of Tartary buckwheat (Fagopyrum tataricum Gaertn.) and some of its milling fractions. J Food Sci 77, C746-C751.

54. Hur SJ, Park SJ \& Jeong CH (2011) Effect of buckwheat extract on the antioxidant activity of lipid in mouse brain and its structural change during in vitro human digestion. J Agric Food Chem 59, 10699-10704.

55. Li Y, Duan S, Jia H, et al. (2014) Flavonoids from Tartary buckwheat induce G2/M cell cycle arrest and apoptosis in human hepatoma HepG2 cells. Acta Biochim Biophys Sin (Shanghai) 46, 460-470.

56. Fang J, Nakamura H \& Iyer AK (2007) Tumor-targeted induction of oxystress for cancer therapy. J Drug Target $\mathbf{1 5}$, 475-486.

57. Vogrinčič M, Kreft I, Filipič M, et al. (2013) Antigenotoxic effect of Tartary (Fagopyrum tataricum) and common (Fagopyrum esculentum) buckwheat flour. J Med Food 16, 944-952.

58. Hertog MG, Feskens EJ, Hollman PC, et al. (1994) Dietary flavonoids and cancer risk in the Zutphen Elderly Study. Nutr Cancer 22, 175-184.

59. Zhang G, Xu Z, Gao Y, et al. (2015) Effects of germination on the nutritional properties, phenolic profiles, and antioxidant activities of buckwheat. J Food Sci 80, H1111-H1119.

60. Kim S, Kim S \& Park C (2004) Introduction and nutritional evaluation of buckwheat sprouts as a new vegetable. Food Res Int 37, 319-327.

61. Koyama M, Nakamura C \& Nakamura K (2013) Changes in phenols contents from buckwheat sprouts during growth stage. J Food Sci Technol 50, 86-93.

62. Lin LY, Peng CC, Yang YL, et al. (2008) Optimization of bioactive compounds in buckwheat sprouts and their effect on blood cholesterol in hamsters. I Agric Food Chem $\mathbf{5 6}$ 1216-1223.

63. Kim DW, Hwang IK, Lim SS, et al. (2009) Germinated buckwheat extract decreases blood pressure and nitrotyrosine immunoreactivity in aortic endothelial cells in spontaneously hypertensive rats. Phytother Res 23, 993-998.

64. Zhou X, Hao T, Zhou Y, et al. (2015) Relationships between antioxidant compounds and antioxidant activities of Tartary buckwheat during germination. J Food Sci Technol 52, 2458-2463.

65. Andriantsitohaina R, Auger C, Chataigneau T, et al. (2012) Molecular mechanisms of the cardiovascular protective effects of polyphenols. Br J Nutr 108, 1532-1549.
66. Rodrigo R, Gil D, Miranda-Merchak A, et al. (2012) Antihypertensive role of polyphenols. Adv Clin Chem 58, 225-254.

67. Wieslander G, Fabjan N, Vogrincic M, et al. (2011) Eating buckwheat cookies is associated with the reduction in serum levels of myeloperoxidase and cholesterol: a double blind crossover study in day-care centre staffs. Tohoku J Exp Med 225, 123-130.

68. Tomotake H, Yamamoto N, Kitabayashi H, et al. (2007) Preparation of Tartary buckwheat protein product and its improving effect on cholesterol metabolism in rats and mice fed cholesterol-enriched diet. J Food Sci 72, S528-S533.

69. Choi I, Seog H, Park Y, et al. (2007) Suppressive effects of germinated buckwheat on development of fatty liver in mice fed with high-fat diet. Phytomedicine 14, 563-567.

70. Wieslander G \& Norbäck D (2001) Buckwheat consumption and its medical and pharmacological effects - a review of the literature. In Proceedings of the 8th International Symposium on Buckwheat - ISB, pp. 608-612. Chunchon, Korea: International Symposium on Buckwheat.

71. Merendino N, Molinari R, Costantini L, et al. (2014) A new "functional" pasta containing Tartary buckwheat sprouts as an ingredient improves the oxidative status and normalizes some blood pressure parameters in spontaneously hypertensive rats. Food Funct 5, 1017-1026.

72. Matsui T, Kudo A, Tokuda S, et al. (2010) Identification of a new natural vasorelaxatant compound, (+)-osbeckic acid, from rutin-free Tartary buckwheat extract. J Agric Food Chem 58, 10876-10879.

73. Ushida Y, Matsui T, Tanaka M, et al. (2008) Endotheliumdependent vasorelaxation effect of rutin-free Tartary buckwheat extract in isolated rat thoracic aorta. $J$ Nutr Biochem 19, 700-707.

74. Chu JX, Li GM, Gao XJ, et al. (2014) Buckwheat rutin inhibits AngII-induced cardiomyocyte hypertrophy via blockade of CaNdependent signal pathway. Iran J Pharm Res 13, 1347-1355.

75. Li CH, Matsui T, Matsumoto K, et al. (2002) Latent production of angiotensin I-converting enzyme inhibitors from buckwheat protein. J Pept Sci $\mathbf{8}, 267-274$.

76. Alvarez P, Alvarado C, Puerto M, et al. (2006) Improvement of leukocyte functions in prematurely aging mice after five weeks of diet supplementation with polyphenol-rich cereals. Nutrition 22, 913-921.

77. Garrett R, Romanos M, Borges R, et al. (2012) Antiherpetic activity of a flavonoid fraction from Ocotea notata leaves. Rev Bras Farmacogn 22, 306-313.

78. Paul IM, Beiler J, McMonagle A, et al. (2007) Effect of honey, dextromethorphan, and no treatment on nocturnal cough and sleep quality for coughing children and their parents. Arch Pediatr Adolesc Med 161, 1140-1146.

79. Ihme $\mathrm{N}$, Kiesewetter H, Jung $\mathrm{F}$, et al. (1996) Leg oedema protection from a buckwheat herb tea in patients with chronic venous insufficiency: a single-centre, randomised, doubleblind, placebo-controlled clinical trial. Eur J Clin Pharmacol 50, 443-447.

80. Ku SK, Lee IC, Han MS, et al. (2014) Inhibitory effects of rutin on the endothelial protein $\mathrm{C}$ receptor shedding in vitro and in vivo. Inflammation 37, 1424-1431.

81. Karki R, Park CH \& Kim DW (2013) Extract of buckwheat sprouts scavenges oxidation and inhibits pro-inflammatory mediators in lipopolysaccharide-stimulated macrophages (RAW264.7). J Integr Med 11, 246-252.

82. Lee CC, Shen SR, Lai YJ, et al. (2013) Rutin and quercetin, bioactive compounds from Tartary buckwheat, prevent liver inflammatory injury. Food Funct 4, 794-802.

83. Kayashita J, Shimaoka I, Nakajoh M, et al. (1999) Consumption of a buckwheat protein extract retards 
7,12-dimethylbenz[ $\alpha]$ anthracene-induced mammary carcinogenesis in rats. Biosci Biotechnol Biochem 63, 1837-1839.

84. Wieslander G, Fabjan N, Vogrincic M, et al. (2012) Effects of common and Tartary buckwheat consumption on mucosal symptoms, headache and tiredness: a double-blind crossover intervention study. J Food Agric Env 10, 107-110.

85. Choi JY, Lee JM, Lee DG, et al. (2015) The $n$-butanol fraction and rutin from Tartary buckwheat improve cognition and memory in an in vivo model of amyloid- $\beta$-induced Alzheimer's disease. J Med Food 18, 631-641.

86. Song K, Kim S, Na JY, et al. (2014) Rutin attenuates ethanolinduced neurotoxicity in hippocampal neuronal cells by increasing aldehyde dehydrogenase 2. Food Chem Toxicol 72, 228-233.

87. Bishnoi M, Chopra K \& Kulkarni SK (2007) Protective effect of rutin, a polyphenolic flavonoid against haloperidol-induced orofacial dyskinesia and associated behavioural, biochemical and neurochemical changes. Fundam Clin Pharmacol 21, $521-529$

88. Lee CC, Lee BH \& Lai YJ (2015) Antioxidation and antiglycation of Fagopyrum tataricum ethanol extract. I Food Sci Technol 52, 1110-1116.

89. Lee CC, Hsu WH, Shen SR, et al. (2012) Fagopyrum tataricum (buckwheat) improved high-glucose-induced insulin resistance in mouse hepatocytes and diabetes in fructose-rich diet-induced mice. Exp Diabetes Res 2012, 375673.
90. Hosaka T, Nii Y, Tomotake H, et al. (2011) Extracts of common buckwheat bran prevent sucrose digestion. J Nutr Sci Vitaminol (Tokyo) 57, 441-445.

91. Curran JM, Stringer DM, Wright B, et al. (2010) Biological response of hepatomas to an extract of Fagopyrum esculentum M. (buckwheat) is not mediated by inositols or rutin. J Agric Food Chem 58, 3197-3204.

92. Cai EP \& Lin JK (2009) Epigallocatechin gallate (EGCG) and rutin suppress the glucotoxicity through activating IRS2 and AMPK signaling in rat pancreatic $\beta$ cells. J Agric Food Chem 57, 9817-9827.

93. Skrabanja V, Liljeberg Elmståhl HG, Kreft I, et al. (2001) Nutritional properties of starch in buckwheat products: studies in vitro and in vivo. J Agric Food Chem 49, 490-496.

94. Takahama U, Tanaka M \& Hirota S (2010) Proanthocyanidins in buckwheat flour can reduce salivary nitrite to nitric oxide in the stomach. Plant Foods Hum Nutr 65, 1-7.

95. Lee YA, Cho EJ, Tanaka T, et al. (2007) Inhibitory activities of proanthocyanidins from persimmon against oxidative stress and digestive enzymes related to diabetes. J Nutr Sci Vitaminol (Tokyo) 53, 287-292.

96. Đurendić-Brenesel M, Popović T, Pilija V, et al. (2013) Hypolipidemic and antioxidant effects of buckwheat leaf and flower mixture in hyperlipidemic rats. Bosn J Basic Med Sci 13, 100-108 